\section{Vox Sanguinis}

Stephen Henry ${ }^{\mathrm{a}}$

Rosella Mollicone ${ }^{\mathrm{b}}$

John B. Lowe

Bo Samuelsson ${ }^{\mathrm{a}}$

Göran Larson ${ }^{\mathrm{a}}$

a Department of Clinical Chemistry and Transfusion Medicine, Göteborg University, Sahlgrenska Hospital, Göteborg, Sweden;

' INSERM U178, Villejuif, France;

${ }^{c}$ Howard Hughes Medical Institute, University of Michigan Medical Centre, MSRBI, Ann Arbor, Mich., USA
Vox Sang 1996;70:21-25

\section{A Second Nonsecretor Allele of the Blood Group $\alpha(1,2)$ Fucosyl- transferase Gene (FUT2)}

\begin{abstract}
While screening $L e(a+b+)$ Polynesian DNA samples for a candidate $S e^{w}$ allele, a point mutation $\left(\mathrm{C}^{571} \rightarrow \mathrm{T}\right)$ resulting in a new stop codon ( $\mathrm{Arg}^{191} \rightarrow$ stop) in the $\alpha(1,2)$ fucosyltransferase gene (FUT2) was identified. This point mutation resulted in the gaining of a new restriction enzyme cleavage site (DdeI), which allowed restriction enzyme cleavage screening of 40 selected Polynesians and 42 random Caucasians. The nonsecretor phenotype in two of the three nonsecretor Polynesians analyzed was due to homozygosity for the 'new' mutation, whereas the third Polynesian nonsecretor (with Caucasian ancestors) was due to homozygosity of the 'old' (Trp ${ }^{143} \rightarrow$ stop) mutation. The nonsecretor phenotype in all Caucasians analyzed was a consequence of homozygosity for the 'old' mutation. Both the new and the old nonsecretor mutations were identified in the heterozygous state in some secretor-positive Polynesians, while only the old mutation was found in the heterozygous state in Caucasians of the same phenotype.
\end{abstract}

\section{Introduction}

Expression of type $1 \mathrm{ABH}$ and $\mathrm{Le}^{\mathrm{b}}$ blood group antigens in human exocrine secretions is determined by the presence of a secretor $(\mathrm{Se})$ gene [reviewed in ref 1]. The term 'secretor' strictly refers to the ability to make large amounts of soluble $\mathrm{A}, \mathrm{B}$ and $\mathrm{H}$ determinants, usually detected in saliva, with the $\mathrm{ABH}$ substances found being dependent on the ABO blood group of the individual [2]. The relative expression of the $\mathrm{Le}^{\mathrm{a}}$ or Le ${ }^{\mathrm{b}}$ antigens is dependent not only on the Lewis genotype but also on the individual's genetically independent secretor genotype. Fucosyltransferases coded by Lewis and secretor genes thus compete with each other and with other glycosyltransferases to determine the Lewis and secretor phenotypes of an individual. In Lewis-negative individuals, the secretor genotype does not affect the Lewis phenotype, but in Lewis-positive individuals, the nonsector

genotype generates the $\mathrm{Le}(\mathrm{a}+\mathrm{b}-)$ red cell phenotype, the secretor genotype causes the $\mathrm{Le}(\mathrm{a}-\mathrm{b}+)$ red cell phenotype, and the partial-secretor genotype gives rise to the $\mathrm{Le}(\mathrm{a}+\mathrm{b}+)$ red cell phenotype [reviewed in ref 3].

Genetic, biochemical and molecular analyses indicate that the Se gene, termed FUT2 in the Genome Data Base, corresponds to an $\alpha(1,2)$ fucosyltransferase gene distinct from the $\mathrm{H}$ blood group $\alpha(1,2)$ fucosyltransferase [4-8]. The recent identification and sequencing of the $S e$ gene predicts a 332 -amino-acid-long polypeptide sharing $68 \%$ sequence identity with the $\mathrm{COOH}$-terminal 292 residues of the human $\mathrm{H}$ blood group $\alpha(1,2)$ fucosyltransferase. A nonsecretor allele, causing the Le $(\mathrm{a}+\mathrm{b}-)$ phenotype in Lewis-positive individuals, corresponded with the homozygous presence of an enzyme-inactivating nonsense point mutation $\left(\operatorname{Tr} p^{143}\right.$ $\rightarrow$ stop) at this locus [9].

Dr. Steve Henry

Department of Clinical Chemistry and Transfusion Medicine Göteborg University

Sahlgrenska Hospital

S-41345 Göteborg (Sweden) 
Determination of secretory phenotypes is usually done serologically by inhibiting $\mathrm{ABH}$ antiserum with saliva. In Lewis-positive individuals, it is sometimes deduced from the direct red cell agglutination test, because $\operatorname{Le}(a-b+)$ and Le $(a+b-)$ red cell phenotypes correlate with secretor and nonsecretor salivary phenotypes, respectively. These techniques, however, may be inaccurate, particularly in certain circumstances (e.g. pregnancy, disease, transfusion, transplantation) and in some populations (e.g. Polynesians [3], Asians [10], Australian aborigines [11]), and so may not necessarily accurately reflect the genotype of an individual [reviewed in ref 3]. Genotyping now offers the opportunity to determine the secretor status of an individual without the requirement to phenotype. However, before this can happen, all alleles should be identified.

In this paper we report the presence of a second FUT2 nonsecretor allele ( $\mathrm{Arg}^{191} \rightarrow$ stop) which in homozygous form correlates with the salivary $\mathrm{ABH}$ nonsecretor and red cell Le $(a+b-)$ phenotype in two Polynesian Lewis-positive individuals.

\section{Materials and Methods}

\section{Samples and Phenotypes}

The 40 Polynesian samples were mostly from previous studies where they were selected on the basis of unusual red cell phenotypes. These samples have been extensively Lewis and secretory phenotyped and in some instances glycolipids were immunochemically profiled $[12-15]$. Lewis phenotypes reported are those based on red cell serology; however, for 3 samples, the Le $(a+b-)$ phenotype was not supported by glycolipid analysis of plasma [15, unpubl. obs.]. These 3 samples $(033,057$ and 114) are examples of the Le $(a+b+)$ phenotype in which the $\mathrm{Le}^{\mathrm{b}}$ reaction on red cells cannot be serologically demonstrated routinely, and these samples have been classified here as $\operatorname{Le}(a+b+)$.

The Caucasian samples were predominantly from another study of Swedish blood donors [16], and although they had been selected on the basis of being predominantly Lewis negative (16/42), no selection was made for secretor phenotypes. The Swedish Caucasian samples were Lewis phenotyped on red blood cells with monoclonal Lewis reagents (Dominion Biologicals, Dartmouth, Canada) and the Lewis-negative samples were salivary ABH phenotyped as described elsewhere [17].

\section{DNA Preparation}

The DNA preparation technique was essentially according to Miller et al. [18]. After lysis of the erythrocytes, the remaining leukocytes/ nuclei were treated with proteinase K in EDTA buffer with SDS. After addition of $5 \mathrm{M} \mathrm{NaCl}$, DNA was extracted from the supernatants by precipitation, washing and drying, and finally dissolved to a concentration of approx $500 \mu \mathrm{g} / \mathrm{ml}$ in TE buffer ( $10 \mathrm{mM}$ Tris- $\mathrm{HCl}, 1 \mathrm{mMNa} \mathrm{Na}_{2}$ EDTA, pH 7.5).

\section{PCR Amplification}

PCR amplification was performed on a PTC-100 Programmable Thermal Controller (MJ Research, Watertown, USA). Half a microgram of genomic DNA was used as template for each amplification reaction. The primers were purchased from Scandinavian Synthesis, Köping, Sweden, and diluted in sterile water to $25 \mu M$ for PCR amplification, and to $0.5 \mu M$ for nucleotide sequencing.

All PCR amplifications were done with heating to $85^{\circ} \mathrm{C}$ for $5 \mathrm{~min}$ before adding $1 \mathrm{U}$ Taq DNA polymerase ( $5 \mathrm{U} / \mu \mathrm{l}$, No. 1435 094, Boehringer Mannheim, Mannheim, Germany). PCR amplification was run for 30 cycles with denaturation at $94^{\circ} \mathrm{C}$ for $1.5 \mathrm{~min}$, annealing/extension for $2.5 \mathrm{~min}$ at $72^{\circ} \mathrm{C}$ and stopped by cooling to $8^{\circ} \mathrm{C}$ [9].

All PCR products and fragments after restriction enzyme cleavage were analyzed by agarose gel electrophoresis in TBE buffer $(45 \mathrm{mM}$ Tris borate, $1 \mathrm{mM} \mathrm{Na} \mathrm{Na}_{2}$-EDTA, $\mathrm{pH} 8.0$ ) with $5 \mu$ ethidium bromide and run at $125 \mathrm{~V}$. The molecular-weight marker used was the $M s p$ I digest of pBR322 DNA (No.73318, United States Biochemical, Cleveland, Ohio, USA).

\section{Nucleotide Sequencing}

PCR-amplified FUT2 gene segments were separated on a $2 \% \mathrm{Nu}-$ Sieve ${ }^{(3)}$ GTG $^{(}$agarose gel (No. 50082, FMC BioProducts, Rockland, Me., USA). The bands were excised, melted and extracted with TE buffer ( $20 \mathrm{~m} M$ Tris- $\mathrm{HCl}, 1 \mathrm{mM} \mathrm{Na}{ }_{2}$-EDTA, $\mathrm{pH} 7.8$ ), partitioned with phenol and the DNA was extracted and precipitated with ethanol. A DNA sequencer model 373A (Applied Biosystems, Calif., USA) and the DyeDeoxy ${ }^{\mathrm{TM}}$ terminator cycle sequencing technique (No. 401095 , Perkin Elmer-Cetus, Calif., USA) were used according to the manufacturer's protocol with Taq DNA and the cyclic amplification reaction run for $15 \mathrm{~s}$ at $96^{\circ} \mathrm{C}, 1 \mathrm{~s}$ at $50^{\circ} \mathrm{C}, 4 \mathrm{~min}$ at $60^{\circ} \mathrm{C}$ and stopped at $4^{\circ} \mathrm{C}$ after 25 cycles. The products were purified by repeated phenol-chloroform extractions, chloroform extraction, precipitation, centrifugation, washing in ethanol and drying. Finally, the samples were dissolved in $6 \mu \mathrm{l}$ of deionized formamide (No. 72020, IBI, New Haven, Conn., USA) containing $50 \mathrm{mM} \mathrm{Na} 2$-EDTA $5: 1$ ( $\mathrm{vol} / \mathrm{vol}$ ) and $3 \%$ blue dextran (no. D-5751, Sigma, St.Louis, Mo., USA), heated for $2 \mathrm{~min}$ at $95^{\circ} \mathrm{C}$, cooled on ice and loaded onto $6 \%$ polyacrylamide sequencing gels.

\section{Mutation Screening with Restriction Enzyme Cleavage}

Restriction enzyme Bst NI (10 U/ $\mu$ l, No. $168 \mathrm{~S}$, New England Biolabs, Beverly, Mass., USA) cleavage identification of the $\operatorname{Trp}^{143} \rightarrow$ stop (nucleotide $\mathrm{G}^{428} \rightarrow \mathrm{A}$ ) mutation was used with PCR products obtained from the primers as described elsewhere [9]. Restriction cleavage products were separated on a $4 \%$ NuSieve GTG agarose gel.

Restriction enzyme DdeI ( $10 \mathrm{U} / \mu \mathrm{l}$, No. 835293, Boehringer Mannheim) cleavage for the $\operatorname{Arg}^{191} \rightarrow$ stop (nucleotide $C^{571} \rightarrow$ T) mutation was used with PCR products obtained from the BstNI sense primer (as above) and a new antisense primer 5'-CGTCCCAATGGTCATGATGGTGTGGTTACA-3'. DdeI cleavage reactions were performed at $37^{\circ} \mathrm{C}$ for $2 \mathrm{~h}$ and the reactions were stopped with gel-loading solution (G 2526, Sigma). Restriction cleavage products were separated on a $2 \%$ agarose gel (No. 15510-027, Gibco-BRL, Paisley, UK).

\section{Results}

The coding sequence of the FUT2 gene of 13 individuals [10 Polynesians: $9 \mathrm{Le}(\mathrm{a}+\mathrm{b}+)$ and $1 \mathrm{Le}(\mathrm{a}-\mathrm{b}-)$ partial secretor; 3 Caucasians: 2 Le $(a+b-)$ and 1 Le $(a-b-)$ secretor] were completely sequenced (both strands). Heterozygosity (C and $\mathrm{T}$ ) of the nucleotide sequence at position 571 (wild type corresponding to $\mathrm{Arg}^{191}$ ) was found in 3 Polynesian sam- 
Table 1. Presence and zygosity of the $B s t$ Nl-determined $s e^{428}$ allele and the Ddeldetermined $s e^{571}$ allele in each Lewis and salivary phenotype for Polynesians and Caucasians

\begin{tabular}{|c|c|c|c|c|c|c|c|}
\hline & \multirow{2}{*}{$\begin{array}{l}\text { Red cell Lewis } \\
\text { phenotype }\end{array}$} & \multirow[t]{2}{*}{$\mathrm{n}$} & \multicolumn{2}{|l|}{$s e^{428}$} & \multicolumn{2}{|l|}{$s e^{571}$} & \multirow{2}{*}{$\begin{array}{l}\text { Un- } \\
\text { mutated }\end{array}$} \\
\hline & & & homo & hetero & homo & hetero & \\
\hline \multicolumn{8}{|l|}{ Polynesians } \\
\hline \multirow[t]{3}{*}{ Secretors } & $\operatorname{Le}(a-b+)$ & 18 & 0 & 2 & 0 & 3 & 13 \\
\hline & $\operatorname{Le}(a+b+)^{a}$ & 14 & 0 & 1 & 0 & 3 & 10 \\
\hline & $\operatorname{Le}(a-b-)$ & 5 & 0 & 0 & 0 & 0 & 5 \\
\hline \multirow[t]{2}{*}{ Nonsecretors } & $\operatorname{Le}(a+b-)$ & 2 & 0 & 0 & 2 & 0 & 0 \\
\hline & $\operatorname{Le}(a-b-)$ & 1 & 1 & 0 & 0 & 0 & 0 \\
\hline \multicolumn{8}{|l|}{ Caucasians } \\
\hline \multirow[t]{2}{*}{ Secretors } & $\operatorname{Le}(a-b+)$ & 20 & 0 & 13 & 0 & 0 & 7 \\
\hline & $\operatorname{Le}(a-b-)$ & 10 & 0 & 6 & 0 & 0 & 4 \\
\hline \multirow[t]{2}{*}{ Nonsecretors } & $\operatorname{Le}(a+b-)$ & 6 & 6 & 0 & 0 & 0 & 0 \\
\hline & $\operatorname{Le}(a-b-)$ & 6 & 6 & 0 & 0 & 0 & 0 \\
\hline
\end{tabular}

Secretors include both normal and partial secretors. homo $=$ Homozygous state of mutated allele; hetero $=$ heterozygous state of mutated allele.

a Includes 3 individuals whose red cells phenotype as $\mathrm{Le}(\mathrm{a}+\mathrm{b}-)$ but by glycolipid analyses are $\operatorname{Le}(\mathbf{a}+\mathbf{b}+)$. ples. Translation of this $\left(\mathrm{C}^{571} \rightarrow \mathrm{T}\right)$ mutation revealed the codon would read as a stop. The mutation also resulted in the gain of a new restriction enzyme cleavage site for $D d e I$.

All available samples were screened with the appropriate restriction enzymes for both the $s e^{428} \mathrm{TRP}^{143} \rightarrow$ stop) and $s e^{571}\left(\mathrm{Arg}^{191} \rightarrow\right.$ stop) mutations (table 1). The Bst NI restriction enzyme cuts a 195-base pair (corresponding to nucleotides 370 to 564) PCR product of the secretor allele ( $\mathrm{Se}$ ) into four fragments (101, 57, 25 and 12), while the nonsecretor allele $\left(s e^{428}\right)$ is identified by the loss of a restriction site and results in three fragments (101, 82 and 12; fig. 1). The DdeI restriction enzyme does not cut a 468-base pair (corresponding to nucleotides 370 to 837 ) PCR product of the secretor allele while the nonsecretor allele $\left(s e^{571}\right)$ is identified by a restriction site resulting in two fragments ( 267 and 201 ; fig. 1).

The $s e^{428}$ mutation was found in a homozygous state in all $6 \mathrm{Le}(\mathrm{a}+\mathrm{b}-)$ and all $6 \mathrm{Le}(\mathrm{a}-\mathrm{b}-)$ nonsecretor Caucasians and in a heterozygous state in 10 of 30 secretor individuals. The remaining 11 secretor individuals were all wild type. The $s e^{428}$ mutation was also found in Polynesians but only in 3 of 37 secretors and homozygously in 1 Le $(\mathrm{a}-\mathrm{b}-$-) nonsecretor. The $s e^{428}$ mutation was not present in the two Le(a+b-) nonsecretor individuals.

In contrast the $s e^{571}$ mutation was absent from the Caucasians but present among Polynesians. This mutation was found in a homozygous state only in the two $\operatorname{Le}(\mathrm{a}+\mathrm{b}-)$ nonsecretor Polynesians (and confirmed by sequencing), and was present in a heterozygous state in 3 of $14 \mathrm{Le}(\mathrm{a}+\mathrm{b}+)$ par- tial secretors, and in 3 of $18 \mathrm{Le}(\mathrm{a}-\mathrm{b}+)$ secretor individuals. No individual had both the DdeI- and Bst NI-determined se alleles.

\section{Discussion}

The common distinction between secretors and nonsecretors of $\mathrm{ABH}$ and/or Lewis substances is made by inhibiting an antiserum agglutinin reaction with saliva. Many variables influence the detection of salivary substances. These include the ethnic group of the donor, ABO and Lewis genotype, saliva collection method and antiserum used. Determination of the salivary ABH secretor phenotype, especially in some populations, can be difficult, if not impossible with routine serological techniques [reviewed in ref. 3]. Furthermore, the inconvenience and reluctance of donors to produce a suitable saliva sample adds to the difficulty of secretor phenotyping. With the recent identification of the coding sequence for the secretor gene [9], restriction enzyme cleavage assays for nonsecretor allele genotyping offer an attractive alternative to salivary and red cell phenotyping. However, as seen here, an alternative nonsecretor allele exists among Polynesians which would not have been detected with the method used for detecting the common $s e^{428}\left(\operatorname{Trp}^{143} \rightarrow\right.$ stop) Caucasian nonsecretor mutation.

In this paper, the second nonsecretor allele, $s e^{571}$ (Arg ${ }^{191} \rightarrow$ stop), was found while screening for a candidate $S e^{\mathrm{w}}$ allele. Subsequent restriction enzyme analysis revealed 


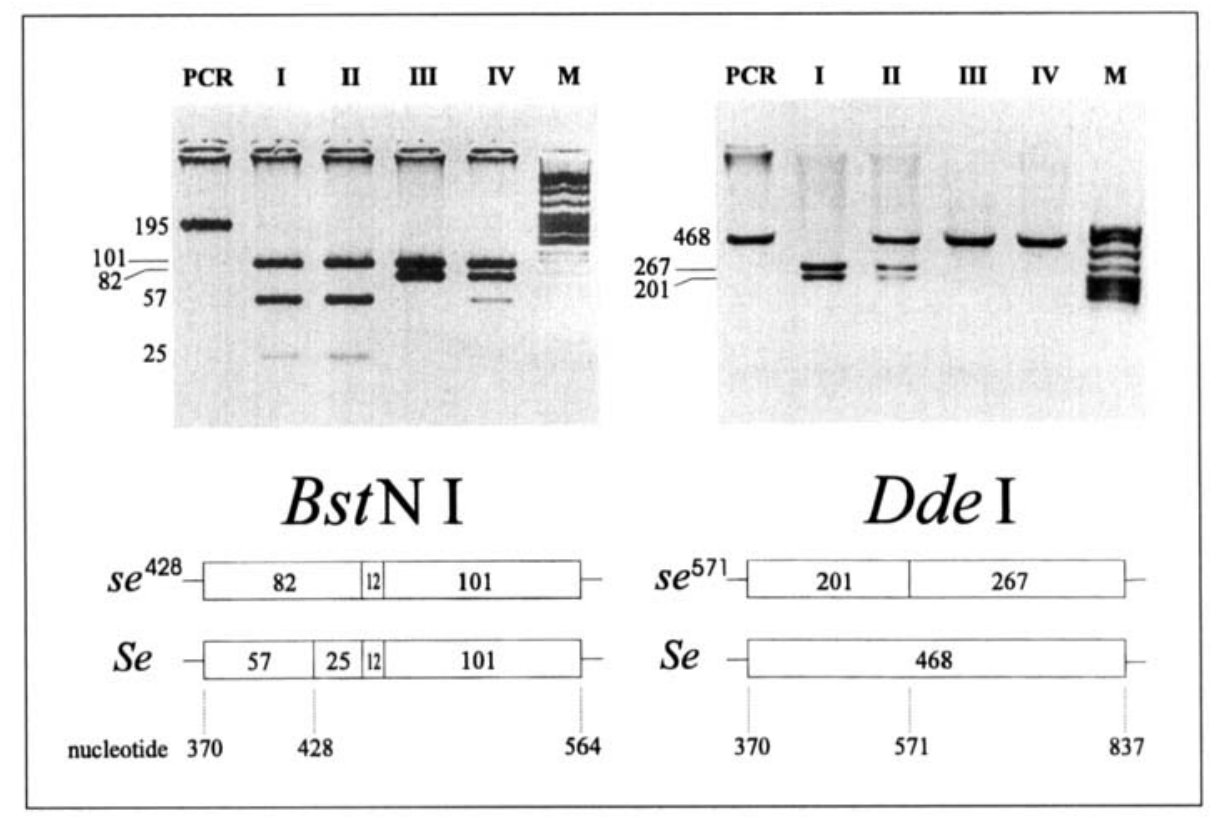

Fig. 1. Examples of the PCR-restriction enzyme cleavage products for the BstNI-determined $s e^{428}$ allele and the DdeI-determined $s e^{571}$ allele. The $s e^{428}$ allele is characterized by the absence of enzyme cleavage of the 82-base pair fragment into 57-and 25-base pair fragments. The $s e^{571}$ allele is characterized by enzyme cleavage of a 468-base pair fragment into 201 - and 267-base pair fragments. $\mathrm{PCR}=$ The uncleaved PCR product of sample 125; $\mathrm{M}=M s p$ I digest of pBR332 molecular-mass marker.

\begin{tabular}{|c|c|c|c|c|c|c|}
\hline \multirow[t]{2}{*}{ Lane } & \multirow[t]{2}{*}{ Individual } & \multirow[t]{2}{*}{$\begin{array}{l}\text { Serological } \\
\text { phenotype (Lewis) }\end{array}$} & \multirow[t]{2}{*}{$\begin{array}{l}\text { Secretor } \\
\text { status }\end{array}$} & \multicolumn{2}{|c|}{$\begin{array}{l}\text { Restriction enzyme } \\
\text { cleavage }^{b}\end{array}$} & \multirow[t]{2}{*}{ Genotype } \\
\hline & & & & $B s t \mathrm{NI}$ & DdeI & \\
\hline I & 125 & $\operatorname{Le}(a+b-)$ & NS & $-1-$ & $+1+$ & $s e^{571} s e^{571}$ \\
\hline II & 128 & $\operatorname{Le}(a-b+)$ & $\mathrm{S}$ & $-1-$ & $-1+$ & Sese $e^{571}$ \\
\hline III & Hen & $\operatorname{Le}(a+b-)$ & NS & $+1+$ & $-1-$ & $s e^{428} s e^{428}$ \\
\hline IV & 113 & $\operatorname{Le}(a-b+)$ & $\mathrm{S}$ & $-1+$ & $-1-$ & $S e s e^{428}$ \\
\hline
\end{tabular}

a $\mathrm{S}=$ Secretor; $\mathrm{NS}=$ nonsecretor.

b $-/-=$ Homozygous negative; $+/+=$ homozygous positive; $+/-=$ heterozygous

that this new mutation was present only in the Polynesian samples and when in a homozygous state correlated with the red cell Le $(a+b-)$ salivary nonsecretor phenotype. In Polynesians, most of the apparently phenotypically Le $(a+b-)$ individuals are in fact $\mathrm{Le}(\mathrm{a}+\mathrm{b}+)$. Detection of the true Le $(a+b-)$ nonsecretor phenotype requires testing with antiserum known to detect weak $\mathrm{Le}^{\mathrm{b}}$ expression and carefully standardized salivary inhibition assays [12]. The two Le $(a+b-)$ Polynesian samples in this study were determined by thorough serological analyses.

The Caucasian $s e^{428}$ nonsecretor allele [9] was present with a frequency equal to the expected gene frequency of this allele in the predominantly Swedish sample. This allele was also found in Polynesians but much less frequently. Furthermore, each of the four Polynesians who had the $s e^{428}$ nonsecretor allele also had a Caucasian ancestor within the last two generations. Because of the selected nature of the Polynesian samples in this study, it is not adequate to estimate gene frequency, but the results suggest that the $s e^{428}$ nonsecretor allele is an infrequent allele in Polynesians compared to Caucasians.

The new point mutation $\left(\mathrm{C}^{571} \rightarrow \mathrm{T}\right)$ identified in the FUT2 gene resulted in $\mathrm{Arg}^{191} \rightarrow$ stop (numbered from the putative initiator methionine [9]). This mutation is predicted to trun- 
cate a large part (141 amino acid residues) of the enzyme catalytic domain on the $\mathrm{COOH}$ terminal segment. The evidence that this mutation yields an inactive allele comes from the fact that this mutation was found in a homozygous state in two known Polynesian red cell Le $(\mathrm{a}+\mathrm{b}-)$ nonsecretor individuals who did not have the Caucasian $s^{428}$ mutation. Furthermore, the new nonsense Polynesian mutation was not found in homozygous form in any of the secretor or partial-secretor individuals. No Caucasian individual had the $s e^{571}$ mutation.

To date, at least one coding secretor allele $\mathrm{Se}$, and two noncoding alleles (termed $s e^{428}$ and $s e^{571}$ ) are known. Further mutations are expected as we have found partial secretors with the red cell $\mathrm{Le}(\mathrm{a}+\mathrm{b}+)$ phenotype who cannot be explained on the basis of these alleles. Molecular genotyp- ing for secretor should now be done in parallel with routine red cell and saliva phenotyping in order to establish the reliability of genotyping, before it can replace saliva phenotyping.

\section{Acknowledgements}

This work was supported by the Medical Faculty, Göteborg University and by grants 6521,8266 and 10436 from the Swedish Medical Research Council, the Swedish Institute, the Wenner-Gren Center Foundation, the Mizutani Foundation for Glycoscience, the IngaBritt and Arne Lundberg Foundation, the Royal Society of Arts and Sciences in Gothenburg, and the Prof. L.E. Gelin Foundation. Drs Rafael Oriol, Anders Elmgren, Graeme Woodfield, Lennart Rydberg and Cecilia Börjeson, Lola Svensson, Holly Perry, and Mansukh Patel are all gratefully acknowledged for their help with this project.

\section{References}

1 Oriol R: ABO, Hh, Lewis and secretion: Serology, genetics and tissue distribution; in Cartron JP, Rouger P (eds): Blood Cell Biochemistry: Molecular Basis of Major Blood Group Antigens. New York, Plenum 1995, pp 37-73.

2 Watkins WM: Biochemistry and genetics of the $\mathrm{ABO}$, Lewis, and $\mathrm{P}$ blood group systems. Adv Hum Genet 1980;10:1-136.

3 Henry SM, Oriol R, Samuelsson BE: Lewis histo-blood group system and associated secretory phenotypes. Vox Sang 1995;69:166-182.

4 Kelly RJ, Ernst LK, Larsen RD, Bryand JG, Robinson JS, Lowe JB: Molecular basis for $\mathrm{H}$ blood group deficiency in Bombay $\left(\mathrm{O}_{\mathrm{h}}\right)$ and parabombay individuals. Proc Natl Acad Sci USA 1994:91:5843-5847.

5 Kumazaki T, Yoshida A: Biochemical evidence that secretor gene, $\mathrm{Se}$, is a structural gene encoding a specific fucosyltransferase. Proc Natl Acad Sci USA 1984;81:4193-4197.

6 Le Pendu J, Cartron JP, Lemieux RU, Oriol R: The presence of at least two different $\mathrm{H}$-bloodgroup-related $\beta D \mathrm{Gal} \alpha-2-L$-fucosyltransferases in human serum and the genetics of blood group $\mathrm{H}$ substances. Am J Hum Genet 1985;37: $749-760$.

7 Oriol R, Danilovs J, Hawkins BR: A new genetic model proposing that the $S e$ gene is a structural gene closely linked to the $H$ gene. Am J Hum Genet 1981;33:421-431
8 Sarnesto A, Köhlin T, Hindsgaul O, Thurin J, Blaszczyk-Thurin M: Purification of the secretor-type $\beta$-galactoside $\alpha 1$-2-fucosyltransferase from human serum. J Biol Chem 1992;267: 2737-2744.

9 Kelly RJ, Rouquier S, Giorgi D, Lennon GG, Lowe JB: Sequence and expression of a candidate for the human secretor blood group $\alpha(1,2)$ fucosyltransferase gene (FUT2): Homozygosity for an enzyme-inactivating nonsense mutation commonly correlates with the non-secretor phenotype. J Biol Chem 1995;270:4640-4649.

10 Broadberry RE, Lin-Chu M: The Lewis blood group system among Chinese in Taiwan. Hum Hered 1991;41:290-294.

11 Vos GH, Comley P: Red cell and saliva studies for the evaluation of $\mathrm{ABH}$ and Lewis factors among the Caucasians and Aboriginal populations of Western Australia. Acta Genet 1967;17: 495-510.

12 Henry SM, Benny AG, Woodfield DG: Investigation of Polynesian Lewis phenotypes: Evidence of a weak secretor phenotype. Vos Sang 1990;58:61-66.

13 Henry SM, Oriol R, Samuelsson BE: Detection and characterisation of Lewis antigens in plasma of Lewis-negative individuals: Evidence of chain extension as a result of reduced fucosyltransferase competition. Vox Sang 1994;67:387396.
14 Henry SM, Samuelsson BE, Oriol R: Immunochemical and immunohistological expression of Lewis histo-blood group antigens in small intestine including individuals of the $\mathrm{Le}(\mathrm{a}+\mathrm{b}+)$ and Le( $(\mathrm{a}-\mathrm{b}-)$ nonsecretor phenotypes. Glycoconj J 1994; 1 1:600-607.

15 Henry SM, Oriol R, Samuelsson BE: Expression of Lewis histo-blood group glycolipids in the plasma of individuals of $\mathrm{Le}(\mathrm{a}+\mathrm{b}+)$ and partial secretor phenotype. Glycoconj J 1994:11: 593-599.

16 Elmgren A, Börjeson C, Svensson L, Rydberg L, Larson G: DNA sequencing and screening for point mutations in the human Lewis (FUT3) gene enables molecular genotyping of the human Lewis blood group system. Vox Sang 1995; in press.

17 Mollison PL, Engelfriet CP, Contreras M: Blood Transfusion in Clinical Medicine. Oxford, Blackwell Scientific, 1993, pp 149-205.

18 Miller SA, Dykes DD, Polesky HF: A simple salting out procedure for extracting DNA from human nucleated cells. Nucleic Acids Res 1988; 16:1215. 